\title{
Lack of mutation in exon 10 of p53 gene in thyroid tumors
}

\author{
Patricia Lia Santarosa ${ }^{a}$, Fabiana Granja ${ }^{a}$, \\ Elaine Cristina Moraria , Janaína Luisa Leitea, \\ Ligia Vera Montalli da Assumpção, Laura S Ward.
}

\section{Ausencia de mutaciones del exón 10 del gen p53 en tumores tiroideos}

\begin{abstract}
Antecedentes: p53 es una proteína nuclear que tiene un rol importante en la regulación de la proliferación celular y comanda cascadas de señalización para la reparación de ADN y apoptosis. En muchos tipos de cáncer, hay una alta frecuencia de mutaciones de p53. Estas mutaciones también son muy prevalentes en el cáncer indiferenciado de tiroides, pero no se encuentran en tumores benignos y son infrecuentes en el cáncer bien diferenciado. La mayor parte de las mutaciones se localizan en los exones 5 a 8 del gen. Recientemente se ha descrito una mutación de la línea germinal del exón 10 en el codón 337 del p53, en niños brasileños con tumores suprarrenales. Objetivo: Buscar mutaciones del codón 337, del exón 10 de p53 en tumores tiroideos. Material y métodos: Se estudiaron 74 tumores tiroideos ( 5 carcinomas foliculares incluyendo 3 altamente invasivos, 22 carcinomas papilares incluyendo 6 variantes con células altas, 11 adenomas foliculares, 1 carcinoma medular y 35 bocios benignos). El $\mathrm{ADN}$ se extrajo de una sección central de los tumores y desde tejidos tiroideo normal contralateral o sangre en 38 pacientes. Los productos de PCR para el exón 10 de p53 fueron examinados por análisis de conformación de polimorfismos de hebra simple. Se secuenciaron 2 muestras en que se sospechó la presencia de bandas con migración aberrante y 3 productos de PCR adicionales provenientes de muestras de tumor con patrones normales de polimorfismo, pero no se detectaron mutaciones. Resultados: En todas las muestras estudiadas, no se detectaron mutaciones. Conclusiones: El exón de p53 no presenta mutaciones en los tumores tiroideos. Esto sugiere que esta mutación es específica para tumores suprarrenales. (Rev Méd Chile 2004; 132: 1513-6)
\end{abstract}

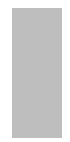

Recibido el 11 de mayo, 2004. Aceptado en versión corregida el 25 de octubre, 2004. Laboratory of Cancer Molecular Genetics, Department of Medicine, Faculty of Medical Sciences, State University of Campinas (FCM/UNICAMP), Campinas, São Paulo, Brazil. aBiologist. Postgraduate doctoral student.
$\mathrm{T}$ he tumor suppressor gene p53 is a transcription factor that acts in cell cycle regulation, inducing cell cycle arrest or cell death in response to DNA-damaging agents, such as viral infection, radiation and chemotherapeutics ${ }^{1}$. The p53 protein resides primarily in the nucleus, binds to specific DNA sequences, and functions at least in part as a transcriptional regulator ${ }^{2}$. Inactivated p53 mutations have been described in some $50 \%$ of human cancers and are believed to be a major determinant of the phenotype of many forms of cancer ${ }^{1-3}$.

Address for correspondence: Laura S Ward. Olympio Pattaro 45, 13085-045 Campinas, São Paulo, Brazil. F/Fax: 55-19-3788.7878 or 3289.4107. E-mail: ward@unicamp.br
Several studies, both with immunocytochemical and genetic analyses, have shown that p53 mutations are highly prevalent in poorly differentiated and undifferentiated thyroid carcinomas, as well as thyroid cancer cell lines ${ }^{4-6}$. However, they are not found in benign tumors and are infrequent in welldifferentiated cancers, suggesting that mutational inactivation of p53 occurs at a late stage of thyroid tumor progression ${ }^{7}$. These data suggest that mutational inactivation of the p53 gene may be a key event in the progression from differentiated to anaplastic carcinoma ${ }^{4,7}$. There is also evidence that p53 may interfere with thyroid cell differentiation. Introduction of a mutated p53 markedly impairs the differen- 
tiated gene expression of PCC13 thyroid cells ${ }^{8}$. By contrast, wild-type p53 reintroduction into an undifferentiated thyroid cancinoma cell line leads to reexpression of thyroid peroxidase, a characteristic differentiated marker of the thyroid cell ${ }^{9}$.

Typically, mutations in p53 gene are located in exons 5-8, a highly conserved DNA binding domain of p53. Recently, a distinct nucleotide substitution in the exon 10 of p53 was identified at a high frequency, 77 to $97 \%$ of children with benign and malignant adrenocortical sporadic tumors investigated by 2 distinct groups ${ }^{10,11}$. This germline mutation leading to an Arg337His mutation of exon 10 was also identified in asymptomatic relatives of the patients but in none of the unrelated controls, suggesting that the mutation is a risk factor associated with adrenocortical tumors rather than a benign polymorphism commonly found in southem Brazil ${ }^{10,11}$.

Sporadic tumors often appear to have the same gene mutations as their familial counterparts. Many germline mutations have been demonstrated to be associated with sporadic tumors, including thyroid cancer ${ }^{12-16}$. We recently showed that a polymorphism at codon 72 of exon 4 of p53 was associated with sporadic thyroid carcinomas ${ }^{17}$.

Because of the high prevalence of the codon 337 of exon 10 of p53 mutation in southern Brazilian population and the possibility that this polymorphism could be also associated to other cancers, we designed this study to screen a large amount of samples for this p53 mutation in thyroid tumors.

\section{MATERIAL AND METHODS}

Subjects. The Ethics Committee of the University Hospital - School of Medicine of the State University of Campinas (HC-FCM/UNICAMP) approved the study and informed written consent was obtained from a total of 74 subjects ( 55 females, 19 males, 16 to 81 years old, $49 \pm 21$ years old) that were consecutively referred to thyroid surgery because of thyroid nodules that presented clinical or epidemiological suspicion of cancer. The diagnosis of thyroid carcinoma was established by fine-needle aspiration cytological study and confirmed by the histological analysis of thyroid tissues. There were 28 thyroid malignant tumors: 5 follicular carcinomas ( 3 widely invasive and 2 minimally invasive); 22 papillary carcinomas (14 of the classic variant, 2 follicular variants, 6 tall cell variants) and 1 medu- llary carcinoma. Other 46 cases (35 females, 11 males, 21 to 75 years old, $47 \pm 19$ years old) of benign goitres included 19 follicular adenomas, 22 multinodular goitres and 5 Basedow-Graves disease. Thyroid tissue samples were obtained at the time of surgery at the University Hospital and immediately frozen in liquid N2. Besides collecting a central portion of all tumors, we obtained samples from the contra lateral normal thyroid lobe of 26 patients with thyroid cancer. In addition, peripheral blood samples were collected from 18 different patients with benign goitres. Tumor stage and degree of differentiation were obtained from surgical and pathological records. Experienced pathologists of the University Hospital of the Faculty of Medical Sciences of the State University of Campinas (UNICAMP) confirmed all diagnoses.

Methods. Genomic DNA was extracted from frozen tumors using a standard phenol-chloroform method. We used the same primers described by Latronico et $\mathrm{al}^{10}$. PCR was performed in $25 \mu \mathrm{l}$ volumes of a mixture containing $100 \mathrm{ng}$ DNA, $50 \mathrm{nM}$ of each primer (5'-CTGAGGCACAAGAATCAC-3' and 5'-TCCTATGGCTTTCCAACC-3'), $10 \mathrm{mM}$ Tris- $\mathrm{HCl}$ (pH 8.0), $1.5 \mathrm{mM} \mathrm{MgCl} 2,100 \mathrm{uM}$ of each dinucleotide triphosphate and 0.5 U Taq DNA polymerase. Amplifications were camied out for 35 cycles of $94^{\circ} \mathrm{C}$ for 45 seconds, $62^{\circ} \mathrm{C}$ for 45 seconds and $72^{\circ} \mathrm{C}$ for $1 \mathrm{~min}$, with an initial denaturation step of $94^{\circ} \mathrm{C}$ for $2 \mathrm{~min}$ and a final extension step of $72^{\circ} \mathrm{C}$ for 7 min using a Perkin-Elmer 9600 GeneAMp PCR system. The amplified $447 \mathrm{bp}$ DNA fragments were examined on a $2 \%$ agarose gel, containing ethidium bromide. After confirming amplification, the samples were mixed with 95\% formamide, $0.05 \%$ bromophenol blue, $0.05 \%$ xylene cyanol and $50 \mathrm{mM} \mathrm{NaOH}$, denatured at $94^{\circ} \mathrm{C}$ for $10 \mathrm{~min}$, and loaded on to $6 \%$ polyacrylamide gels. The electrophoresis was conducted at $2-5 \mathrm{~W}$ at room temperature overnight. The gel was then stained with silver nitrate. DNA samples homo and heterozygous for the Arg337His mutation, obtained from adrenocortical tumors, were used as positive controls of the gels.

\section{RESULTS}

Figure 1 depicts an example of our results. All samples showed the same pattern of running, with no significant differences. Two samples suspected of presenting aberrant migrating bands were exci- 
sed from the gel and purified using a commercial kit according to the manufacturer's instructions (Life Technologies, Paisley, UK). PCR products were sequenced with the ABI prism big dye sequencing kit (Perkin Elmer, Warrington, Cheshire, UK) using an ABI 377 Prism DNA Sequencer (Perkin Elmer). In all cases a wild-type sequence was found. In addition, we directly sequenced 3 additional PCR products from tumor samples with normal SSCP patterns, and all were wild type.

\section{DisCUSSION}

The p53 gene is one of the best studied tumor suppressor genes, located on chromosome 17p13.1. Its mutation has been reported mainly in aggressive forms of tumors, especially anaplastic carcinomas ${ }^{18}$. It has been found in up to $40 \%$ of dedifferentiated and undifferentiated thyroid carcinomas and in less than $10 \%$ of the differentiated thyroid tumors ${ }^{19}$. However, mutant p53 protein has also been detected in follicular and papillary carcinomas $^{20}$. More recently, p53 mutant protein was also demonstrated in 11 out of 66 nodular hyperplasia cases (16.7\%) and in 7 out of 50 (14\%) cases of follicular adenomas ${ }^{21}$.

Although somatic mutations of p53 are the most common genetic changes observed to date, the frequency of germline p53 mutations is found to be very low in sporadic malignant tumors ${ }^{4}$. It has been postulated that de novo germline p53 mutations may occur in a substantial population of patients in the pediatric age group, who die of their disease and do not propagate the mutation ${ }^{22,23}$. On the other hand, recent reports suggest that germline p53 splicing mutations have been described infrequently in the literature because the method of mutation detection, in many studies, does not include all splice junctions24. The low figures reported in the literature might also reflect the use of less-sensitive mutation detection methods and, certainly, the fact that most researches focused on exons 5-8, within the DNAbinding domain of p53, instead of screening all 11 exons of TP5324. Indeed, because $85 \%$ of p53 mutations are expected to occur in exons 5 through 8, thyroid tumor screening efforts, in almost all reports, were restricted to these regions of the gene (http://www.iarc.fr/p53/; http://cancergenetics.org/ p53.htm).

The spectrum and frequency of cancers associated with germline p53 mutations are uncertain. Some cancers like breast carcinoma, soft tissue sarcomas, osteosarcoma, brain tumors, adrenocortical carcinoma, Wilms' tumor and phyllodes tumor are strongly associated with germline p53 mutations while carcinoma of pancreas is moderately associated and leukaemia and neuroblastoma are weakly associated 25 .

Screening exon 10 by PCR-SSCP and by direct sequencing, we did not find mutations in a large number of thyroid samples. These results support the concept that germline TP53 mutations do not simply increase general cancer risk. Instead, they promote tissue-specific effects. Although our results are constrained by the fact that we did not screen poorly differentiated or undifferentiated tumors, they suggest that the Arg337His germline mutation described in Brazilian children is restricted to adrenocortical tumors.

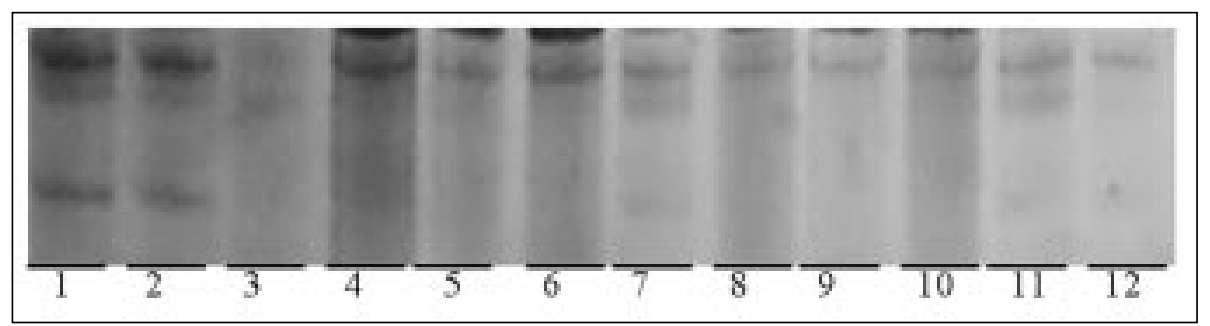

FIGURE 1. Gel of single-stranded conformation polymorphism analysis of PCR products (PCR-SSCP) representative of our results for exon 10 of p53 gene screening for mutations. Lanes 1 and 2 were loaded with the positive controls for the homo- and the heterozygous Arg337His mutation of exon 10 of the p53 gene, respectively. Lanes 3-7 and 8-12 were loaded with PCR products from follicular and papillary carcinomas, respectively. 


\section{REFERENCES}

1. LeviNE AJ. p53, the cellular gatekeeper for growth and division. Cell 1997; 88: 323-31.

2. Mendoza-Rodríguez CA, CerBon MA. Tumor suppressor gene p53: mechanisms of action in cell proliferation and death. Rev Invest Cl 2001; 53: 266-73.

3. GoodseLL DS. The molecular perspective: p53 tumor suppressor. Oncologist 1999; 4: 138-9.

4. FARD NR. p53 mutations in thyroid carcinoma: tidings from an old foe. J Endocrinol Invest 2001; 24: 536-45.

5. Shahedian B, Shi Y, Zou M, Farid NR. Thyroid carcinoma is characterized by genomic instability: evidence from p53 mutations. Mol Gen Metab 2001; 72: 155-63.

6. Smida J, Zitzelsberger H, Kelierer AM, Lehmann L, Minkus G, Negele T ET AL. p53 mutations in childhood thyroid tumors from Belarus and in thyroid tumors without radiation history. Int J Cancer 1997; 73: 802-7.

7. WARD LS, FAGIN JA. Molecular genetics of thyroid cancer: evidence that inactivation of tumor suppressor genes occurs at late stages of tumor progression. Molecular and Cellular Pediatric Endocrinology. New Jersey: editor Handwerger S, 1998; 201-11.

8. Battista S, Martew ML, Fedele M, Chiappetta G, Trapasso F, DE VITA G ET AL. A mutated p53 alters differentiation of thyroid cells. Oncogene 1995; 72: 2029-37.

9. Fagin JA, Tang S-H, Zeki K, Di Lauro R, Fusco A, GonsKY R. Reexpression of thyroid peroxidase in a derivative of an undifferentiated thyroid carcinoma cell line by introduction of wild-type p53. Cancer Res 1996; 56: 765-71.

10. Latronico AC, Pinto EM, Domenice S, Fragoso MC, Martin RM, ZerBinI MC ET AL. An inherited mutation outside the highly conserved DNA-binding domain of the p53 tumor suppressor protein in children and adults with sporadic adrenocortical tumors. J Clin Endocr Metab 2001; 86: 4970-3.

11. Ribeiro RC, Sandrini F, Figueiredo B, Zambetti GP, MichalKIEWICZ E, LAFFeRTY AR ET AL. An inherited p53 mutation that contributes in a tissue-specific manner to pediatric adrenal cortical carcinoma. P Nat Acad Sci USA 2001; 98: 9330-5.

12. Olveira C, Ferreira P, Nabais S, Campos L, Ferreira A, CIRNES L et AL. E-Cadherin (CDH1) and p53 rather than SMAD4 and Caspase-10 germline mutations contribute to genetic predisposition in Portuguese gastric cancer patients. Eur J Cancer 2004; 40: 1897-903.

13. Lim W, Olschwang S, Kelerer JJ, Westerman AM, MenKo FH, Boardman L et aL. Relative frequency and morphology of cancers in STK11 mutation carriers. Gastroenterology 2004; 126: 1788-94.
14. Chang BL, Zheng SL, Isaacs SD, Wiley KE, Turner A, $\mathrm{LI} G$ ET AL. A polymorphism in the CDKN1B gene is associated with increased risk of hereditary prostate cancer. Cancer Res 2004; 64: 1997-9.

15. HARACH HR. Familial adenomatous polyposis associated with sporadic MEN 1 and thyroid carcinoma related to APC mutation. Am J Surg Pathol 2003; 27: 412-3.

16. ENG C. The role of PTEN, a phosphatase gene, in inherited and sporadic nonmedullary thyroid tumors. Recent Prog Horm Res 1999; 54: 441-52.

17. Granja F, Morari J, Morari EC, Correia LA, AssumPÇÃO LVM, WARD LS. Proline homozygozity in codon 72 of p53 is a factor of susceptibility for thyroid cancer. Cancer Letters 2004; 210: 151-7.

18. FAGIN JA. Molecular pathogenesis of follicular ephitelium. In: Braverman $\mathrm{LE}$, Utiger $\mathrm{RD}$, editors. Werner's and Ingbar's The Thyroid. 8th ed. Boston: Lippincott Williams \& Wilkins, 2000; 886-98.

19. Goretzki PE, Dotzenrath C, Simon D, Roher H-D. Studies of oncogenes and tumor suppressor genes in human thyroid carcinomas, and their clinical implications. Langenbecks Arch Surg 1999; 384: 1-8.

20. Hosal SA, Apel RL, Freeman JL, Azadian A, Rosen IB, LIVOLSI VA ET AL. Immunohistochemical localization of p53 in human thyroid neoplasms: correlation with biologic behavior. Endocr Pathol 1997; 8: 218.

21. Omar E, Madhavan M, Othman NH. Immunohistochemical localization of RET and p53 mutant protein of thyroid lesions in a North-Eastern Malaysian population and its prognostic implications. Pathology 2004; 36: 152-9.

22. Saed GM, Ladin D, Olson J, Han X, Hou Z, Fivenson D. Analysis of p53 gene mutations in keloids using polymerase chain reaction-based single-strand conformational polymorphism and DNA sequencing. Arch Dermatol 1998; 134: 963-7.

23. Birch JM, Alston RD, McNaluy RJ, Evans DG, Kelsey AM, HARRIS M ET AL. Relative frequency and morphology of cancers in carriers of germline TP53 mutations. Oncogene 2001; 20: 4621-8.

24. Variey JM, Attwooll C, White G, McGown G, THORNCROFT M, KeISEY AM ET AL Characterization of germline TP53 splicing mutations and their genetic and functional analysis. Oncogene 2001; 20: 2647-54.

25. Frebourg T. Germline mutations of the p53 gene. Pathol Biol (Paris) 1997; 45: 845-51.

Acknowledgment.

We thank Dr. Berenice B Mendonça from the Department of Medicine - Endocrinology, USP - São Paulo, for kindly providing us with the adrenal samples used as positive controls in this research. 